\title{
RESEARCHPAPER
}

\section{Biological management of pigeonpea stem canker caused by Macrophomina phaseolina (Tassi) Goid}

\author{
D.M. Pathak and R.R.Patel
}

Department of Plant Pathology, College of Agriculture, Navsari Agricultural University, Campus Bharuch-Maktampur (Gujarat) India

Email : dmpathak@nau.in

Article Info : Received : 08.08.2019; Revised : 10.09.2019; Accepted : 25.09.2019

Seven known antagonists were tested in vitro for their antagonism to M. phaseolina by dual culture method. In this method, Trichoderma viride, T. harzianum and Pseudomonas fluorescens appeared as strong and potent antagonists against M. phaseolina followed by T. fasciculatum, T. longibrachyatum, T. koningii and Bacillus subtilis.

Key words : Pigeonpea stem canker, Macrophomina phaseolina

How to cite this paper : Pathak, D.M. and Patel, R.R. (2019). Biological management of pigeonpea stem canker caused by Macrophomina phaseolina (Tassi) Goid. Asian J. Bio. Sci., 14 (1\&2) : 8-11.DOI : 10.15740/HAS/AJBS/14.1\&2/8-11. Copyright@ 2019: Hind Agri-Horticultural Society. 